\title{
TOKSISITAS EKSTRAK BUAH MAHKOTA DEWA (Phaleria papuena Warb.) TERHADAP ULAT GRAYAK (Spodoptera litura F.) DI LABORATORIUM
}

\author{
Irvan Zestyadi R.S., Solikhin \& Nur Yasin \\ Jurusan Agroteknologi, Fakultas Pertanian, Universitas Lampung \\ Jl. Prof. Soemantri Brojonegoro, No. 1 Bandar Lampung 35145 \\ Email: irvanzestyadi@gmail.com
}

\begin{abstract}
ABSTRAK
Dalam budidaya tanaman, salah satu kendala utama yang menjadi penghambat produksi baik secara kualitas maupun kuantitas adalah adanya serangan organisme pengganggu tanaman. Salah satu hama yang menyerang budidaya tanaman adalah ulat grayak (Spodoptera litura F.). Tujuan dari penelitian ini untuk mengetahui toksistas ekstrak buah mahkota dewa (Phaleria papuena Warb.) terhadap ulat grayak (Spodoptera litura F.). Penelitian ini menggunakan 6 perlakuan ekstrak buah mahkota dewa. Pada setiap satuan percobaan digunakan 15 ekor ulat grayak yang dipapari ekstrak buah mahkota dewa. Perlakuan yang digunakan adalah konsentrasi ekstrak buah mahkota dewa yang terdiri atas 6 taraf konsentrasi, yaitu 0\%, 1\%, 5\%, 10\%, $20 \%, 30 \%$. Untuk memperoleh nilai $\mathrm{LC}_{50}$ data mortalitas yang diperoleh pada uji toksisitas ekstrak buah mahkota dewa (Phaleria papuena Warb.) terhadap ulat grayak (Spodoptera litura F.) dilakukan analisis probit dengan software menggunakan SPSS v23 for windows. Nilai $\mathrm{LC}_{50}$ ditentukan pada taraf nyata 5\%. Hasil penelitian menunjukkan bahwa ekstrak buah mahkota dewa dapat mematikan ulat grayak. Nilai $\mathrm{LC}_{50}$ ekstrak buah mahkota dewa terhadap larva Spodoptera litura F. yaitu 7,98\% pada 8 hari setelah aplikasi. Semakin tinggi konsentrasi ekstrak buah mahkota dewa yang digunakan maka akan semakin cepat dalam mematikan ulat grayak, semakin tinggi konsentrasi ekstrak buah mahkota dewa $\mathrm{LT}_{50}$-nya semakin rendah.
\end{abstract}

Kata kunci: Ekstrak buah mahkota dewa, mortalitas ulat grayak, nilai $\mathrm{LC}_{50}$, nilai $\mathrm{LT}_{50}$

\section{PENDAHULUAN}

Dalam budidaya tanaman, salah satu kendala utama yang menjadi penghambat produksi baik secara kualitas maupun kuantitas adalah adanya serangan organisme pengganggu tanaman, terutama hama ulat. Salah satu hama yang menyerang budidaya tanaman adalah ulat grayak (Spodoptera litura F.). Ulat grayak merupakam hama penting pada daun karena mempunyai kisaran inang yang luas, meliputi kedelai, kacang tanah, sawi, kubis, ubi jalar, kentang. Ulat grayak menyerang tanaman budidaya pada fase vegetatif yaitu memakan daun tanaman yang muda sehingga tinggal tulang daun saja (Budi, dkk., 2013).

Ulat grayak Spodoptera litura F. adalah salah satu jenis hama pemakan daun yang dapat menyebabkan kerusakan berat pada tanaman kedelai. Hama ini bersifat polifag, dengan kisaran inang luas, tidak terbatas pada tanaman pangan, tetapi juga menyerang tanaman perkebunan, sayuran, dan buah-buahan. Pada kondisi endemis di kebun percobaan Muneng, Probolinggo, pada tahun 2009 terjadi 100\% defoliasi/kerusakan daun dan kehilangan hasil yang disebabkan oleh hama ulat grayak (Suharsono dan Muchlis, 2010). Pengendalian ulat grayak dapat dilakukan dengan berbagai cara. Salah satu caranya dengan menggunakan pestisida nabati. Pestisida nabati merupakan salah satu alternatif yang dapat digunakan dalam pengendalian hama tanaman. Salah satu bahan tanaman yang dapat digunakan sebagai pestisida nabati adalah buah mahkota dewa.

Buah mahkota dewa (Phaleria papuena Warb.) mengandung zat aktif seperti alkaloid, tannin, flavonoid, fenol, saponin, lignin, minyak atsiri dan sterol. Racun buah mahkota dewa tidak membunuh hama secara cepat, namun mengganggu hama pada proses metamorfosis, makan, pertumbuhan, reproduksi dan lainnya (Anggraini, 2009).

Hasil penelitian Anggraini (2009), menunjukkan bahwa ekstrak buah mahkota dewa dapat digunakan sebagai pestisida nabati untuk mengendalikan hama ulat daun kubis (Plutella xylostella L.) pada tanaman caisin. Dari hasil penelitian tersebut konsentrasi ekstrak buah mahkota dewa terendah $0,27 \%$ menyebabkan kematian sebesar 20\% dan kosentrasi tertinggi $70 \%$ menyebabkan kematian sebesar $66,7 \%$, sedangkan kematian $50 \%$ $\left(\mathrm{LC}_{50}\right)$ terjadi pada konsentrasi $17,5 \%$.

Penelitian ini bertujuan untuk mengetahui toksistas ekstrak buah mahkota dewa (Phaleria papuena Warb.) terhadap ulat grayak (Spodoptera litura F.). 


\section{BAHAN DAN METODE}

Penelitian ini dilaksanakan di Laboratorium Bioteknologi, Fakultas Pertanian, Universitas Lampung pada bulan September sampai Desember 2016.

Penyediaan pakan ulat grayak. Tanaman yang digunakan sebagai pakan serangga uji adalah tanaman brokoli. Perbanyakan tanaman brokoli dilakukan dengan menggunakan media tanam campuran tanah dan pupuk kandang (1:1) yang dimasukkan dalam polibag dan dipelihara dalam rumah kaca. Sebelum dilakukan penyemaian benih brokoli direndam menggunakan air hangat terlebih dahulu selama 15 menit. Bibit semai brokoli membutuhkan waktu 2 minggu setelah tanam untuk melakukan pemindahan bibit ke polibag. Perawatan tanaman brokoli dilakukan setiap hari, dari awal melakukan penyemaian sampai tanaman brokoli siap untuk dijadikan sebagai pakan ulat grayak.

Pengumpulan ulat grayak. Dalam penelitian ini dibutuhkan 90 ekor ular grayak. Larva ulat grayak dikumpulkan dari lahan pertanaman sayuran petani dan dikembangbiakkan di dalam stoples dengan pakan daun brokoli lalu ditempatkan di laboratorium. Selama dalam perbanyakan, ulat grayak diberi pakan setiap hari sambil melakukan pembersihan stoples dari kotoran dan sisa pakan pada stoples tersebut. Setelah menjadi imago, ngengat dipindahkan ke dalam stoples lain yang berisi kapas yang diolesi madu 50\%. Ngengat dipelihara agar menghasilkan telur yang banyak. Setelah telur menetas, larva instar I berganti kulit menjadi larva instar II. Larva yang sudah mencapai larva instar II inilah yang digunakan untuk pengujian.

Pembuatan ekstrak buah mahkota dewa. Daging buah mahkota dewa ditimbang sebanyak $1 \mathrm{~kg}$ lalu diiris untuk memudahkan ekstraksi setelah itu dicuci dan dikeringkan. Air disiapkan sebanyak 1 liter kemudian dicampur dengan buah mahkota dewa kemudian diblender. Hasil blender dimasukan ke dalam stoples besar lalu ditutup dan dibiarkan selama 24 jam (Bunaiyah, dkk., 2013). Larutan yang diperoleh adalah ekstrak pekat (konsentrasi 50\%).

Pengenceran konsentrasi ekstrak buah mahkota dewa dilakukan dengan rumus sebagai berikut:

$$
\mathrm{V}_{1} \mathrm{M}_{1}=\mathrm{V}_{2} \mathrm{M}_{2}
$$

Keterangan:

$\mathrm{V}_{1}=$ jumlah larutan mula-mula $(\mathrm{ml})$

$\mathrm{M}_{1}=$ konsentrasi larutan mula-mula (\%)

$\mathrm{V}_{2}=$ jumlah larutan akhir $(\mathrm{ml})$

$\mathrm{M}_{2}=$ konsentrasi larutan akhir (\%)
Dengan pengenceran tersebut didapatkan sejumlah larutan ekstrak buah mahkota dewa dengan beberapa tingkat konsentrasi, yaitu 30\%, 20\%, 10\%, 5\%, dan $1 \%$. Sebagai contoh cara pembuatan ekstrak buah mahkota dewa konsentrasi $30 \%\left(\mathrm{M}_{2}\right)$ yaitu sebanyak $60 \mathrm{ml}$ ekstrak pekat buah mahkota dewa $\left(\mathrm{V}_{1}\right)$ dengan konsentrasi awal 50\% ( $\left.\mathrm{M}_{1}\right)$ dimasukkan ke dalam gelas ukur. Dengan menggunakan rumus tersebut maka akan diperoleh volume akhir $\left(\mathrm{V}_{2}\right)$ sebesar $100 \mathrm{ml}$. Dengan demikian air yang perlu ditambahkan sebagai bahan pengencer larutan yaitu sebesar $40 \mathrm{ml}(100 \mathrm{ml}-60 \mathrm{ml}$ $=40 \mathrm{ml}$ ).

Aplikasi ekstrak buah mahkota dewa. Daun brokoli pakan ulat dicelupkan selama 2 menit ke dalam konsentrasi ekstrak buah mahkota dewa yang telah disiapkan, kemudian dikeringkan selama 10 menit, setelah itu daun brokoli diletakkan ke dalam stoples yang berisi ulat grayak. Stoples ditutup kembali dengan kain kasa untuk meminimalisasikan kegagalan akibat lingkungan sekitar. Selanjutnya dilakukan pengamatan harian terhadap gejala fisik dan kematian ulat grayak sampai muncul imago.

Berdasarkan uji pendahuluan yang telah dilakukan, ekstrak buah mahkota (Phaleria papuena Warb.) mampu mematikan ulat grayak (Spodoptera litura F.). Uji pendahuluan dilakukan dengan menggunakan 10 ekor ulat grayak instar II untuk setiap stoples dengan 3 ulangan dan pengamatan dilakukan selama 48 jam. Dari hasil uji pendahuluan diperoleh bahwa pada kontrol (tanpa ekstrak) didapatkan total kematian 2 ekor ulat grayak $(6,6 \%)$, konsentrasi $5 \mathrm{ml}$ ekstrak ditambah $95 \mathrm{ml}$ air $(2,5 \%)$ dapat mematikan 9 ekor ulat grayak (30\%), konsentrasi $25 \mathrm{ml}$ ekstrak ditambah $75 \mathrm{ml}$ air (12,5\%) dapat mematikan 29 ekor ulat grayak $(96,6 \%)$. Hasil uji pendahuluan ini dijadikan dasar untuk menentukan konsentrasi ekstrak buah mahkota dewa yang digunakan untuk penelitian selanjutnya.

Pengamatan. Peubah yang diamati pada penelitian ini meliputi mortalitas harian (\%) dengan menghitung jumlah ulat grayak yang mati sejak 24 jam setelah aplikasi (JSA) dan gejala yang timbul pada ulat grayak setelah dilakukan pengaplikasian ekstrak buah mahkota dewa.

Analisis Data. Untuk memperoleh nilai $\mathrm{LC}_{50}$ data mortalitas yang diperoleh pada uji toksisitas ekstrak buah mahkota dewa (Phaleria papuena Warb.) terhadap ulat grayak (Spodoptera litura F.) dilakukan analisis probit dengan software menggunakan SPSS v23 for windows. Nilai $\mathrm{LC}_{50}$ ditentukan pada taraf nyata $5 \%$. 


\section{HASIL DAN PEMBAHASAN}

Toksisitas ekstrak buah mahkota dewa. Setelah aplikasi ekstrak buah mahkota dewa kematian ulat grayak nonkumulatif dapat dilihat pada Gambar 1, sedangkan kematian ulat grayak kumulatif dapat dilihat pada Gambar 2. Gambar 1 menunjukkan bahwa setelah 8 HSA tidak ada lagi tambahan kematian ulat grayak. Dalam hal ini pada konsentrasi 30\% semua ulat uji (15 ekor) sudah mati pada hari ke-4. Tetapi, pada konsentrasi 1-20\% tidak ada tambahan kematian pada hari ke-9 karena masih ada ulat uji yang hidup dan menjadi pupa.

Gambar 2 menunjukkan konsentrasi ekstrak buah mahkota dewa 30\% menyebabkan daya bunuh yang paling cepat terhadap ulat grayak. Pada hari ke-4 total kematian ulat grayak sudah mencapai 15 ekor $(100 \%)$, sedangkan pada konsentrasi terendah $1 \%$ total kematian ulat grayak sampai hari terakhir pengamatan hanya 6 ekor (40\%).

Nilai $L C_{50}$ hasil analisis probit. Konsentrasi yang digunakan dalam penelitian ini adalah $0,1,5,10$, 20, dan 30\%. Pada konsentrasi perlakuan dari terendah sampai tertinggi (1-30\%) didapatkan persentase kematian ulat grayak berturut-turut sebesar $40 \%, 53 \%$, $80 \%, 93 \%$, dan $100 \%$. Sedangkan pada kontrol (tanpa perlakuan) tidak ada ulat grayak yang mati pada 12 hari setelah aplikasi (HSA). Data hasil penelitian selanjutnya dianalisis probit menggunakan software SPSS v23 for windows untuk mendapatkan nilai $\mathrm{LC}_{50}$. Hasil analisis $\mathrm{LC}_{50}$ menunjukkan bahwa konsentrasi ekstrak buah mahkota dewa 7,98\% (kisaran 1,09\%-12,81\%) memberikan efek toksik terhadap $50 \%$ populasi larva

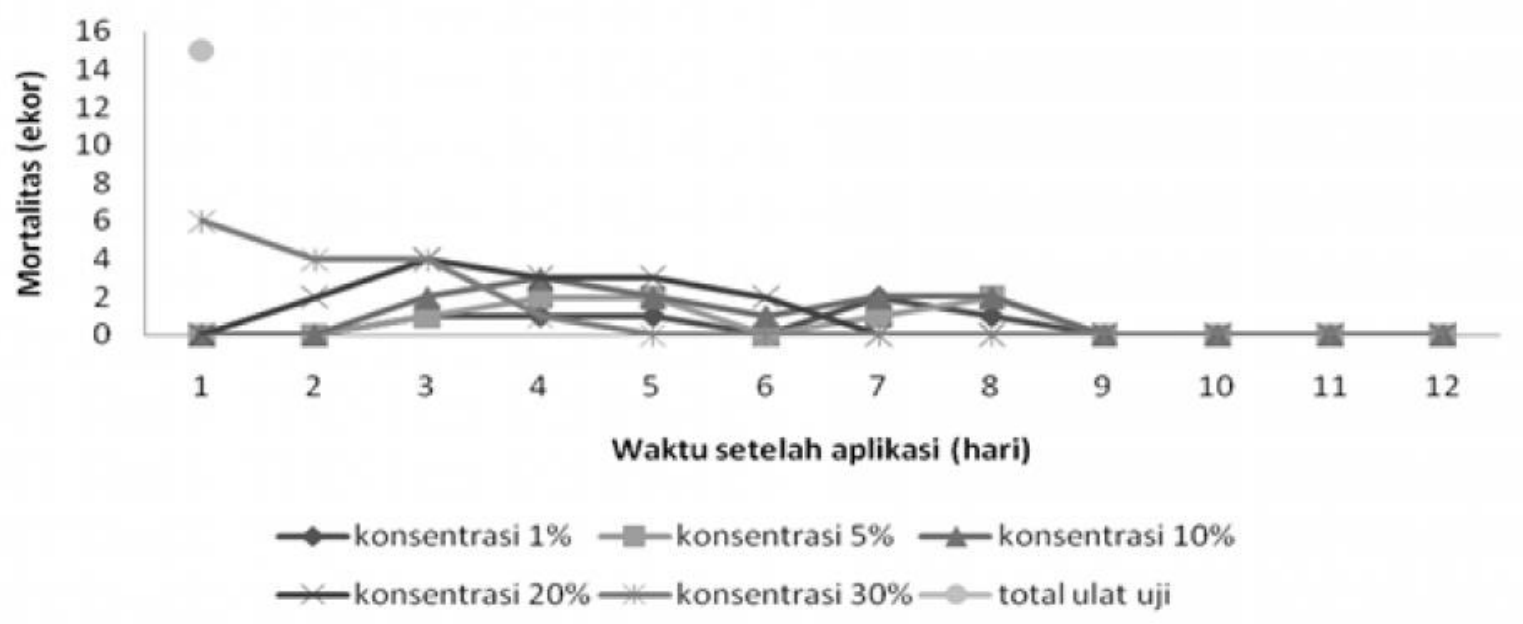

Gambar 1. Kurva ulat grayak yang mati nonkumulatif setelah aplikasi ekstrak buah mahkota dewa.

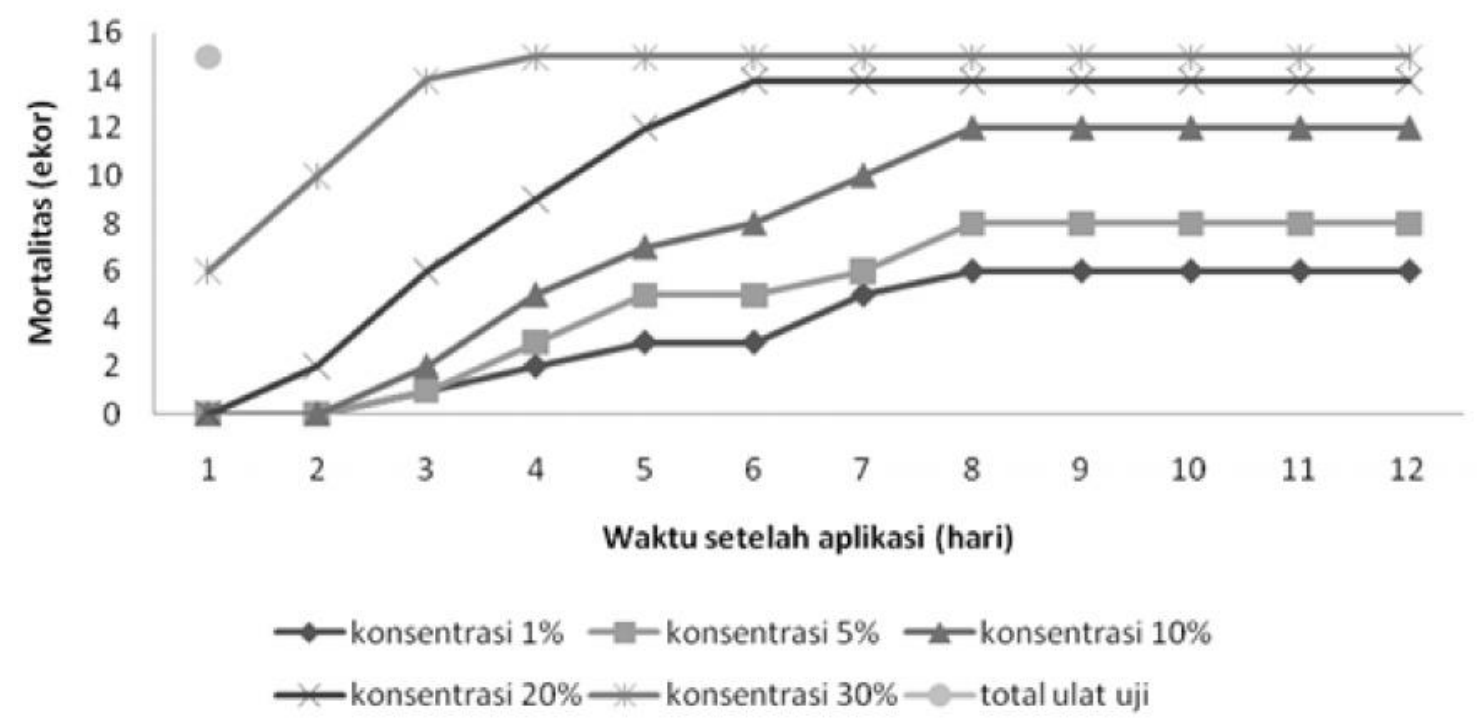

Gambar 2. Kurva ulat grayak yang mati kumulatif setelah aplikasi ekstrak buah mahkota dewa. 
Spodoptera litura $\mathrm{F}$., yang berarti nilai $\mathrm{LC}_{50}$ pada 8 HSA yaitu 7,98\%.

Nilai $L T_{50}$ hasil analisis probit. Dari hasil data kematian harian selanjutnya data dianilisis probit menggunakan SPSS v23 for windows untuk mendapatkan nilai $\mathrm{LT}_{50}$. Hasil analisis probit untuk $\mathrm{LT}_{50}$ terhadap ulat grayak dapat dilihat pada Tabel 1. Tabel 1 menunjukkan bahwa semakin tinggi konsentrasi ekstrak buah mahkota dewa nilai $\mathrm{LT}_{50}$-nya semakin kecil. Pada konsentrasi ekstrak mahkota dewa 30\% didapatkan bahwa mortalitas 50\% ulat grayak terjadi kisaran hari ke-2 setelah aplikasi, sedangkan pada konsentrasi $1 \%$ mortalitas $50 \%$ ulat terjadi pada kisaran hari ke-12 setelah aplikasi, dan pada kontrol atau tanpa perlakuan tidak terjadi kematian pada ulat grayak.

Perubahan perilaku. Aplikasi ekstrak buah mahkota dewa terhadap ulat grayak menyebabkan ulat grayak keracunan dan mati. Gejala keracunan ulat grayak ditunjukkan dengan daun brokoli yang hanya sedikit termakan karena berkurangnya nafsu makan ulat grayak tersebut, dan gerakan yang pasif (lamban). Sedangkan kematian ulat grayak ditandai dengan bau yang tidak sedap, keluarnya lendir, dan tubuh menyusut. Ciri-ciri mortalitas pada ulat grayak dapat dilihat pada Gambar 3.

Toksisitas ekstrak buah mahkota dewa. Ekstrak buah mahkota dewa berpotensi sebagai pestisida nabati karena buah mahkota dewa mengandung alkaloid, tannin, flavonoid, fenol, saponin, lignan, minyak astiri, dan sterol (Anggraini, 2009). Menurut Suparjo (2008), saponin mempunyai efek antimikroba, zat penghambat jamur dan melindungi tanaman dari serangga. Senyawa-senyawa yang terkandung dalam buah mahkota dewa berpotensi dijadikan racun perut dan racun kontak bagi serangga. Hal ini menunjukkan bahwa ekstrak buah mahkota dewa mengandung senyawa beracun yang bisa mematikan ulat grayak
(Naim, 2004). Menurut Djojosumarto (2000), toksisitas atau daya racun pestisida adalah sifat bawaan pestisida yang menggambarkan potensi pestisida tersebut dapat mengakibatkan kematian langsung pada hewan tingkat tinggi. Toksisitas dinyatakan dalam $\mathrm{LC}_{50}$.

Hasil analisis probit dari data yang diperoleh dalam penelitian ini menunjukkan bahwa nilai $\mathrm{LC}_{50}$ ekstrak buah mahkota dewa terhadap larva ulat grayak yaitu 7,98\% pada 8 hari setelah aplikasi (HSA). Dalam penelitian Anggraini (2009) diketahui bahwa ekstrak buah mahkota dewa juga dapat menyebabkan kematian pada larva $P$. xylostella, dan menunjukkan $\mathrm{LC}_{50}$ sebesar 17,5\%. Dari hasil penelitian tersebut dapat dilihat bahwa nilai $\mathrm{LC}_{50}$ ekstrak buah mahkota dewa terhadap ulat grayak jauh lebih kecil. Dengan kata lain ekstrak buah mahkota dewa diduga lebih toksik terhadap larva Spodoptera litura F. dibandingkan terhadap larva P. xylostella. Berbeda dengan penelitian Watuguly dan Wihelminus (2007), ekstrak buah mahkota dewa menunjukkan toksisitas yang signifikan terhadap larva Aedes aegypti, dengan nilai $\mathrm{LC}_{50}$ sebesar $0,09 \%$.

$\mathrm{LT}_{50}$ hasil analisis probit dari perbandingan data yang diperoleh menunjukkan bahwa nilai $\mathrm{LT}_{50}$ berada dalam kisaran waktu 2 hari pada konsentrasi 30\%, sedangkan pada konsentrasi $1 \%$ nilai LT $_{50}$-nya didapatkan dalam kisaran waktu 12 hari. Hasil penelitian ini menunjukkan bahwa semakin tinggi konsentrasi ekstrak buah mahkota dewa yang digunakan akan semakin cepat daya bunuh ekstrak mahkota dewa terhadap ulat grayak (Spodoptera litura F.).

Perubahan perilaku ulat grayak. Berdasarkan penelitian yang telah dilakukan, terlihat perubahan tingkah laku pada ulat grayak setelah diberi pakan yang telah diaplikasikan ekstrak buah mahkota dewa. Perubahan yang terjadi adalah pergerakan yang pasif dan nafsu makan yang berkurang sehingga ulat grayak kelaparan dan mati. Hasil ini didukung oleh Batubara,

Tabel 1. Nilai $\mathrm{LT}_{50}$ hasil analisis probit terhadap waktu kematian ulat grayak.

\begin{tabular}{cccc}
\hline $\begin{array}{c}\text { Konsentrasi } \\
(\%)\end{array}$ & Dugaan & BT50 (hari) & \\
\cline { 2 - 4 } & 12,427 & 7,954 & 21,073 \\
5 & 8,996 & 5,888 & 12,753 \\
10 & 5,697 & 4,061 & 7,179 \\
20 & 3,456 & 2,359 & 4,457 \\
30 & 2,065 & 0,487 & 2,682 \\
\hline
\end{tabular}

* Hasil analisis probit dengan taraf nyata $5 \%$ 

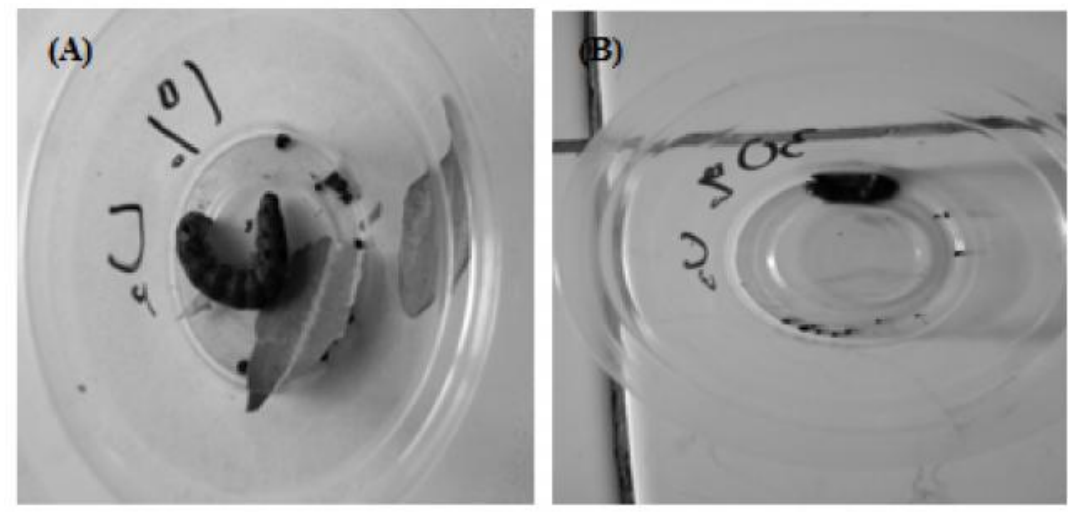

Gambar 3. Ulat grayak yang masih sehat (A), ulat grayak yang sudah mati setelah diberi pakan brokoli yang telah dicelupkan ke dalam ekstrak buah mahkota dewa (B).

dkk. (2012) yang menyatakan bahwa senyawa alkoloid dan flavonoid pada buah mahkota dewa dapat bersifat toksik terutama melalui penghambatan sistem saraf serangga yang berdampak mengurangi nafsu makan.

\section{KESIMPULAN}

Berdasarkan hasil penelitian dapat disimpulkan bahwa ekstrak buah mahkota dewa dapat mematikan ulat grayak. Hasil analisis menunjukkan nilai $\mathrm{LC}_{50}$ ekstrak buah mahkota dewa terhadap larva S.litura yaitu 7,98\% pada 8 hari setelah aplikasi dan semakin tinggi konsentrasi ekstrak buah mahkota dewa yang digunakan maka akan semakin cepat dalam mematikan ulat grayak atau dengan kata lain semakin tinggi konsentrasi ekstrak buah mahkota dewa $\mathrm{LT}_{50}$-nya semakin rendah.

\section{DAFTAR PUSTAKA}

Anggraini, O. D. 2009. Uji efektivitas ekstrak mahkota dewa (Phaleria papuena warb.) terhadap mortalitas ulat daun kubis (Plutella xylostella 1.) pada tanaman caisin. Skripsi. Fakultas Pertanian. Universitas Sebelas Maret.

Batubara, I., S. Kotsuka, H. Yamauchi, T. Kuspradini, Mitsunaga, dan L.K. Darusman. 2012. TNF-á Production inhibitory activity, phenolic, flavonoid and tannin contents of selected indonesian medicinal plants. Research Journal of Medicinal Plant. 6 (6): 406-415.
Budi, A.S., A. Afandhi, dan R.D. Puspitarini. 2013. Patogenisitas jamur entomopatogen beauveria bassiana balsamo (Deuteromycetes : Moniliales) pada larva Spodoptera litura Fabricius (Lepidoptera : Noctuidae). Jurnal HPT. 1(1): 79-83

Bunaiyah, T. Wahyuni, dan U.P. Astuti. 2013. Petunjuk Teknis Pembuatan Pestisida Nabati. Balai Pengkajian Teknologi Pertanian (BPTP) Bengkulu. Bengkulu.

Djojosumarto, P. 2000. Teknik Aplikasi Pestisida Pertanian. Kanisius. Yogyakarta.

Naim, R. 2004. Senyawa antimikroba dari tanaman. Available online at http://www.repository.unhas. ac.id, [15 Februari 2017].

Suharsono dan A. Muchlis. 2010. Identifikasi Sumber Ketahanan Aksesi Plasma Nutfah Kedelai untuk Ulat Grayak Spodoptera litura F. Balai Penelitian Tanaman Kacang-kacangan dan Umbiumbian. Malang.

Suparjo. 2008. Saponin. Laboratorium Makanan Ternak. Fakultas peternakan. Universitas Jambi. Jambi.

Watuguly dan T. Wihelmus. 2007. Uji toksisitas bioinsektisida ekstrak biji mahkota dewa (Phaleria papuana Warb.) terhadap mortalitas nyamuk Aedes aegypti Linn di laboratorium. Available online at http://www.adln.lib.unair.ac.id, [15 Juni 2016]. 